Supplement of Atmos. Chem. Phys., 14, 4573-4585, 2014

http://www.atmos-chem-phys.net/acp-14-4573-2014/

doi:10.5194/acp-14-4573-2014-supplement

(C) Author(s) 2014. CC Attribution 3.0 License.

(c) (1)

Supplement of

\title{
Impact of biomass burning on haze pollution in the Yangtze River delta, China: a case study in summer 2011
}

\section{Z. Cheng et al.}

Correspondence to: S. Wang (shxwang@tsinghua.edu.cn) 
1 Table S1 Site information for the field campaign in the YRD region.

\begin{tabular}{|c|c|c|c|c|}
\hline $\begin{array}{l}\text { Site } \\
\text { Location }\end{array}$ & $\begin{array}{l}2010 \text { city } \\
\text { population } \\
\text { (million) }\end{array}$ & $\begin{array}{l}\text { Elevation } \\
\text { (MSL, m) }\end{array}$ & $\begin{array}{l}\text { Inlet height } \\
(\mathrm{AGL}, \mathrm{m})\end{array}$ & Surrounding conditions \\
\hline Ningbo & 7.6 & 7 & 17 & $\begin{array}{l}\text { Residential \& commercial } \\
\text { area, no industrial sources or } \\
\text { fugitive dust nearby, } 225 \mathrm{~m} \\
\text { south to Liuting Street. }\end{array}$ \\
\hline Hangzhou & 8.7 & 14 & 13 & $\begin{array}{l}\text { Residential \& commercial } \\
\text { area, Construction site } \\
\text { nearby, no industrial sources } \\
\text { nearby, } 275 \text { m west to Shixin } \\
\text { South Road. }\end{array}$ \\
\hline Shanghai & 23.0 & 5 & 20 & $\begin{array}{l}\text { Residential \& commercial } \\
\text { area, no industrial sources or } \\
\text { fugitive dust nearby, } 115 \mathrm{~m} \\
\text { east to Yuanshen Road. }\end{array}$ \\
\hline Suzhou & 10.5 & 6 & 15 & $\begin{array}{l}\text { Residential \& commercial } \\
\text { area, no industrial sources } \\
\text { nearby, } 300 \mathrm{~m} \text { west to } \\
\text { Nanyuan South Road, } 360 \mathrm{~m} \\
\text { north to S Ring Road } \\
\text { Elevated Bridge. }\end{array}$ \\
\hline Nanjing & 8.0 & 30 & 15 & $\begin{array}{l}\text { College district, no industrial } \\
\text { sources or fugitive dust } \\
\text { nearby, } 123 \mathrm{~m} \text { west to Huju } \\
\text { Road. }\end{array}$ \\
\hline
\end{tabular}

2

3 a: the data source is from the sixth nationwide population census of China in 2010

4 (http://www.stats.gov.cn/tjgb/rkpcgb/). 
Table S2 Instruments and analytical method used for filed observation.

\begin{tabular}{|c|c|c|c|}
\hline Type & Observations & $\begin{array}{l}\text { Averaging } \\
\text { time }\end{array}$ & Instrumentation and analytical method \\
\hline \multirow{6}{*}{$\begin{array}{l}\text { Meteorological } \\
\text { parameters }\end{array}$} & Temperature, Relative humidity, & 1 hour & Met Station One (Met One Corp., OR, US) (Suzhou, Ningbo) \\
\hline & Wind speed/direction & & TH-2009 (Tianhong Corp., Hubei, China) (Nanjing) \\
\hline & & & WXT520 (Vaisala Corp., Finland) (Shanghai) \\
\hline & & & WS 600 (LUFFT Corp., CA, US) (Hangzhou) \\
\hline & Visual range & 1 hour & $\begin{array}{l}\text { Model } 6000 \text { (Belfort Instrument Corp., MD, US) (Suzhou, } \\
\text { Hangzhou, Ningbo) }\end{array}$ \\
\hline & & & PWD22 (Vaisala Corp., Finland) (Shanghai, Nanjing) \\
\hline \multirow[t]{2}{*}{$\begin{array}{l}\text { PM mass } \\
\text { concentration }\end{array}$} & $\mathrm{PM}_{2.5}, \mathrm{PM}_{10}$ & 1 hour & $\begin{array}{l}\text { TEOM } 1405^{\text {a }} \text { (Thermo Scientific Corp., MA, US) (Shanghai, } \\
\text { Nanjing, Suzhou, Hangzhou) }\end{array}$ \\
\hline & & & R\&P1400a (Thermo Scientific Corp., MA, US) (Ningbo) \\
\hline \multirow[t]{6}{*}{$\mathrm{PM}_{2.5}$ species $^{\mathrm{b}}$} & Mass concentration & $22 \mathrm{hrs}^{\mathrm{c}}$ & $\begin{array}{l}\text { Partisol } 2300 \text { Speciation Sampler (Thermo Scientific Corp., } \\
\text { MA, US) }\end{array}$ \\
\hline & & & $\begin{array}{l}\text { Filter gravimetric weighting: Mettler Toledo XP6 } \\
\text { Microbalance }\end{array}$ \\
\hline & & & Filter equilibrium condition: RH $40 \pm 5 \%$, Temperature $20 \pm 2^{\circ} \mathrm{C}$ \\
\hline & $\begin{array}{l}\text { Water-soluble ions } \\
\left(\mathrm{NH}_{4}^{+}, \mathrm{Na}^{+}, \mathrm{K}^{+}, \mathrm{Ca}^{2+}, \mathrm{Mg}^{2+}, \mathrm{SO}_{4}{ }^{2-} \text {, }\right. \\
\left.\mathrm{NO}_{3}^{-}, \mathrm{Cl}^{-}\right)\end{array}$ & $22 \mathrm{hrs}^{\mathrm{c}}$ & $\begin{array}{l}\text { Ion chromatography (Dionex-3000, Dionex Corp,CA,US) } \\
\text { (Chow and Watson, 1999) }\end{array}$ \\
\hline & $\begin{array}{l}\text { Carbonaceous component } \\
\text { (organic carbon, elemental } \\
\text { carbon) }\end{array}$ & $22 \mathrm{hrs}^{\mathrm{c}}$ & $\begin{array}{l}\text { IMPROVE-TOR (DRI Model 2001A Carbon Analyzer, } \\
\text { Atmoslytic Inc., CA, US)(Chow et al., 2007) }\end{array}$ \\
\hline & $\begin{array}{l}\text { Elements (Al, As, Br, } \mathrm{Ca}, \mathrm{Cr}, \mathrm{Cu} \text {, } \\
\mathrm{Fe}, \mathrm{Mn}, \mathrm{Ni}, \mathrm{Pb}, \mathrm{Rb}, \mathrm{Se}, \mathrm{Si}, \mathrm{Sr}, \mathrm{Ti} \\
\text { and } \mathrm{Zn} \text { ) }\end{array}$ & $22 \mathrm{hrs}^{\mathrm{c}}$ & $\begin{array}{l}\text { X-Ray Fluorescence (Epsilon } 5 \text { ED-XRF, PANalytical B.V., } \\
\text { the Netherlands) (Cao et al., 2012) }\end{array}$ \\
\hline
\end{tabular}

2 a: The heating temperature of TEOM 1405 and $\mathrm{R} \& \mathrm{P} 1400$ are $50^{\circ} \mathrm{C}$.

3 b: $\mathrm{PM}_{2.5}$ species are available for the sites of Shanghai, Suzhou and Nanjing.

4 c: 22 hours refers to $14: 00$ to $12: 00$ of the next day. 
For Table S1, The Ningbo and Shanghai sites were near the East China Sea

2 where they can be influenced by marine weather systems. The Suzhou site was east of

3 Taihu Lake, the third largest freshwater lake in China. The Hangzhou and Nanjing

$4 \quad$ sites were bordered on three sides by mountains with elevations up to $400 \mathrm{~m}$.

For Table S2, PM2.5 sampling were conducted by Thermo Partisol ${ }^{\circledR}-2300$

6 Speciation Sampler's two parallel channels. Teflon-membrane filters were weighed

7 before and after analysis to calculate mass concentrations, then submitted to $\mathrm{x}$-ray

8 fluorescence (XRF) analysis for $\mathrm{Al}, \mathrm{As}, \mathrm{Br}, \mathrm{Ca}, \mathrm{Cr}, \mathrm{Cu}, \mathrm{Fe}, \mathrm{Mn}, \mathrm{Ni}, \mathrm{Pb}, \mathrm{Rb}, \mathrm{Se}, \mathrm{Si}, \mathrm{Sr}$,

$9 \mathrm{Ti}$ and $\mathrm{Zn}$ concentrations (Cao et al., 2012). A $0.5 \mathrm{~cm}^{2}$ punch from the quartz-fiber

10 filter was submitted to the IMPROVE_A thermal-optical reflectance protocol (Chow

11 et al., 1993,2007,2011) to quantify organic carbon (OC) and elemental carbon (EC).

12 The remaining quartz-fiber filter was extracted in distilled-deionized water by

13 ultrasonic and analyzed for cations $\left(\mathrm{NH}_{4}^{+}, \mathrm{Na}^{+}, \mathrm{K}^{+}, \mathrm{Ca}^{2+}, \mathrm{Mg}^{2+}\right)$ and anions

$14\left(\mathrm{SO}_{4}{ }^{2-}, \mathrm{NO}_{3}{ }^{-}, \mathrm{Cl}^{-}, \mathrm{F}^{-}\right)$by ion chromatography (IC) (Chow and Watson, 1999). Sampling

15 flow rate was $10 \mathrm{~L} / \mathrm{min}$ for quartz-fiber filter (47mm, Whatman QMA, UK) and 16.7

$16 \mathrm{~L} / \mathrm{min}$ for Teflon-membrane filter $(47 \mathrm{~mm}$, Whatman QMA, UK). Flow rate of 17 sampler was calibrated and tested daily by Gilibrator II Flowmeter (Sensidyne, US)

18 and the bias was $\leqq \pm 5 \%$. Sampling cartridge was cleaned daily with methanol 19 moistened Kimwipes while the $\mathrm{PM}_{2.5}$ impactor was cleaned weekly and coated with 20 grease. Prior to sampling quartz-fiber filters were preheated to $600{ }^{\circ} \mathrm{C}$ for 5 hours to 21 remove the absorbed VOCs (Watson et al., 2009; Chow et al., 2010). All samples were 22 stored air-tight in a refrigerator at about $4{ }^{\circ} \mathrm{C}$ after sampling before gravimetric or 23 chemical analysis.

24 The carbon analyzer was calibrated routinely with known quantities of methane 25 such as sucrose solution (Chow et al., 2011). Replicate OC/EC analyses were 26 performed on $10 \%$ of the samples. Standard reference solutions produced by the 27 National Research Center for Certified Reference Materials in China were 28 interspersed every 10 samples during IC measurement and each sample was analyzed 29 twice. Before and after sampling the Teflon filter was equilibrated using controlled 30 temperature $\left(18-22^{\circ} \mathrm{C}\right)$ and relative humidity $(35-45 \%)$ dessicators for $24 \mathrm{~h}$ prior to 31 weighing. Average field blanks were subtracted from the measured concentration of 32 all samples for all compositions. 


\section{References}

2 Cao, J., Wang, Q., Chow, J. C., Watson, J. G., Tie, X., Shen, Z., Wang, P., and An, Z.: Impacts of aerosol compositions on visibility impairment in Xi'an, China, Atmospheric Environment, 59, 559-566, 10.1016/j.atmosenv.2012.05.036, 2012.

Chow, J. C, Watson, J., Robles, J., Wang, X., Chen, L. W. A., Trimble, D., Kohl, S., Tropp, R., and Fun K.: Quality assurance and quality control for thermal/optical analysis of aerosol samples for organic and elemental carbon, Anal Bioanal Chem, 401, 3141-3152, 10.1007/s00216-011-5103-3, 2011.

Chow, J. C., and Watson, J. G.: Ion chromatography in elemental analysis of airborne particles, Elemental analysis of airborne particles, 1, 97-137, 1999.

Chow, J. C., Watson, J. G., Chen, L. W. A., Chang, M. C. O., Robinson, N. F., Trimble, D., and Kohl, S.: The IMPROVE_A Temperature Protocol for Thermal/Optical Carbon Analysis: Maintaining Consistency with a Long-Term Database, Journal of the Air \& Waste Management Association, 57, 1014-1023, 10.3155/1047-3289.57.9.1014, 2007.

Chow, J. C., Watson, J. G., Chen, L. W. A., Rice, J., and Frank, N. H.: Quantification of PM2.5 organic carbon sampling artifacts in US networks, Atmos. Chem. Phys., 10, 5223-5239, 10.5194/acp-10-5223-2010, 2010.

Watson, J. G., Chow, J. C., Chen, L. W. A., and Frank, N. H.: Methods to Assess Carbonaceous Aerosol Sampling Artifacts for IMPROVE and Other Long-Term Networks, Journal of the Air \& Waste Management Association, 59, 898-911, 10.3155/1047-3289.59.8.898, 2009. 